Religare, ISSN: 19826605, v.16, n.1, agosto de 2019, p.207-227.

\title{
Três Modelos Pedagógicos para o Ensino Religioso Escolar
}

\author{
Three Pedagogical Models for School Religious Education
}

Selson Garutti ${ }^{1}$

\section{Resumo}

Atualmente em diversos eventos e debates relativos ao Ensino Religioso Escolar tem ocupado um importante espaço em pesquisas com relação à questão do lugar pedagógico ocupado pelo Ensino Religioso na Escola. Assim, pretende-se por objetivo investigar os três modelos pedagógicos possíveis para o Ensino Religioso Escolar: Catequético, Teológico e da Ciência da Religião (PASSOS, 2006; 2007); (SOARES, 2009; 2010; 2015). Para tanto, propõe-se uma pesquisa bibliográfica documental (FONSECA, 2002) baseada no método qualitativo (MINAYO, 2001). Conclui-se ser o método da Ciência da Religião o qual melhor atende as demandas educacionais da disciplina do Ensino Religioso Escolar.

Palavras-chave: Epistemologia. Educação. Ciências da Religião.

\section{Abstract}

Currently in several events and debates related to School Religious Education has occupied an important space in researches regarding the question of the pedagogical place occupied by Religious Education in the School. Thus, the objective is to investigate the three possible pedagogical models for School Religious Teaching: Caquetic, Theological and the Science of Religion (PASSOS, 2006; 2007); (SOARES, 2009; 2010; 2015). For that, a documental bibliographic research (FONSECA, 2002) based on the qualitative method is propose (MINAYO, 2001). It is concluded that it is the method of the Science of Religion which best meets the educational demands of the discipline of School Religious Education.

Keywords: Epistemology; Education; Religion Studies.

\footnotetext{
${ }^{1}$ Bacharel em Teologia pela Faculdade Nossa Senhora da Assunção de São Paulo, Licenciado em Filosofia pela Universidade do Sagrado Coração de Bauru (USC), Licenciado em História pela Universidade Estadual de Maringá (UEM), Licenciado em Pedagogia pela Faculdade Instituto Superior de Educação do Paraná (FAINSEP), Especialista em Pesquisa Educacional pela Universidade Estadual de Maringá (UEM), Mestre em Ciências da Religião pela Pontifícia Universidade Católica de São Paulo (PUCSP) e Doutor em Educação pela Universidade Estadual de Ponta Grossa (UEPG). Professor de Filosofia pela Secretária de Educação do Estado do Paraná (SEED-PR).
} 
Religare, ISSN: 19826605, v.16, n.1, agosto de 2019, p.207-227.

\section{Introdução}

A sociedade traz consigo fenômenos diversos, entre os quais, destaca-se o religioso, o qual deve ser analisado também no âmbito escolar. Esse fenômeno tem por base: crenças, comportamentos, atitudes e convicções. Nessa perspectiva, a escola precisa não só propiciar condições de boa convivência entre os diferentes, deve também propiciar condições de análise da constituição histórica destas diferenças.

O foco se fixa "na análise da relação de alteridade na educação a partir da discussão de conceitos da diferença" para a boa convivência com os que comungam crenças divergentes. Com expectativa de que a alteridade propicie tolerância religiosa em detrimento ao preconceito e discriminação, produzindo assim formação política sociocultural do aluno como sujeito histórico, permeado pela ética das diferenças e contribuindo assim, para além de outros elementos, a tolerância entre sujeitos diferentes (SANTOS, 2015, p.10).

É nesse contexto que o ensino religioso escolar serve como instrumento de promoção ao respeito a todos os sujeitos (respeito do "EU" "Comigo mesmo", do "Eu" "com o Outro" e do "Eu" "com a Natureza") dilacerando a intolerância incrustada na sociedade.

A concepção de Ensino Religioso Escolar constituído pela lei nº 9.475/97 vai ao encontro da perspectiva "acerca do papel da alteridade na religião" referendada na prática escolar, delineando uma mudança no paradigma do Ensino Religioso Escolar (ROBBINS, 2008, p.139).

Tal proposição expressa um avanço pedagógico frente às atuais exigências conjunturais, quando proporciona aproximações entre diversos credos, caracterizando um Ensino Religioso Escolar que seja capaz de contribuir para tolerância entre sujeitos com diferentes crenças religiosas. Diferenças as 
Religare, ISSN: 19826605, v.16, n.1, agosto de 2019, p.207-227.

quais estão para além da escola, compreendendo a totalidade (SANTOS; SOMMERMAN, 2009).

\section{Metodologia}

A partir do objetivo de investigar os três modelos pedagógicos possíveis para o Ensino Religioso Escolar: Catequético, Teológico e da Ciência da Religião; Para tanto, propõe-se uma pesquisa básica de abordagem qualitativa, a qual se preocupa com aspectos da realidade que não podem ser quantificados, centrando-se na compreensão e explicação da dinâmica das relações sociais.

Assim, Minayo (2001) define pesquisa qualitativa como aquela que:

[...] trabalha com o universo de significados, motivos, aspirações, crenças, valores e atitudes, o que corresponde a um espaço mais profundo das relações, dos processos e dos fenômenos que não podem ser reduzidos à operacionalização de variáveis. Aplicada inicialmente em estudos de Antropologia e Sociologia, como contraponto à pesquisa quantitativa dominante, tem alargado seu campo de atuação a áreas como a Psicologia e a Educação. A pesquisa qualitativa é criticada por seu empirismo, pela subjetividade e pelo envolvimento emocional do pesquisador (MINAYO, 2001, p. $14)$.

O que permite construir múltiplas relações entre os diferentes contextos vividos pelos sujeitos (BOGDAN; BIKLEN; 1994).

O procedimento técnico se caracteriza por ser uma pesquisa bibliográfica, a qual:

[...] é feita a partir do levantamento de referências teóricas já analisadas e publicadas Por meios escritos e eletrônicos como livros artigos científicos páginas de web sites qualquer trabalho científico inicia-se com uma pesquisa bibliográfica que permite ao pesquisador conhecer o que já se estudou sobre o assunto existem, porém pesquisas científicas que se baseia unicamente na pesquisa bibliográfica procurando referenciar teorias públicas com objetivo de recolher informações ou 
Religare, ISSN: 19826605, v.16, n.1, agosto de 2019, p.207-227.

conhecimentos prévios sobre o problema a respeito do qual se procura a resposta (FONSECA, 2002, p. 32).

Bem como, por uma pesquisa documental, a qual:

[...] trilha os mesmos caminhos da pesquisa bibliográfica não sendo fácil por vezes distingui-las a pesquisa bibliográfica utiliza Fontes constituídas por materiais já elaborados constituídos basicamente por livros e artigos científicos localizado em bibliotecas a pesquisa documental recorre a Fontes mais diversas e dispersas sem tratamento analítico tais como tabelas estatísticas jornais revistas e relatórios documentos oficiais cartas filmes fotografia pintura Tapeçaria relatório de empresa vídeo de programas de televisão etc. (FONSECA, 2002, p.32).

Por fim, a coleta de dados foi feita nas obras de Passos (2006; 2007) e Soares $(2009 ; 2010 ; 2015)$, as quais foram tratadas como fontes documentais nessa pesquisa.

\section{Dilemas entre o dogmatismo e a epistemologia religiosa}

O Ensino Religioso Escolar atualmente é a disciplina mais desafiadora por causa da sua fundamentação epistemológica. Esse texto parte da premissa de que o "Ensino Religioso, de matrícula facultativa, é parte integrante da formação básica do cidadão" (Art. nº 33; Lei no 9.394/96).

Para tanto, faz-se necessário estabelecer claramente não só a sua nomenclatura, como também, esclarecer mais ainda qual seja o seu objeto de pesquisa. Assim, parece fundamental correlacionar a duas concepções pedagógicas, de forma tal, a estarem em consonância, desembocando a necessária demanda reprimida sobre esta área de conhecimento.

Como o Ministério da Educação demorou em estabelecer os Parâmetros Curriculares Nacionais para o Ensino Religioso, em outubro de 1996 o Fórum Nacional Permanente do Ensino Religioso elaborou e entregou o documento ao 
Religare, ISSN: 19826605, v.16, n.1, agosto de 2019, p.207-227.

Ministério da Educação. O qual foi um avanço explícito por significar um salto qualitativo em relação às "aulinhas de religião confessionais" que ainda existiam (FONAPER, 2001).

Para o Fonaper (2001, p. 5), o Ensino Religioso tem "como objeto o Transcendente", objeto o qual evoluiu para o fenômeno religioso, presente nas tradições religiosas, como seu objeto de estudo, o qual deve permear os conteúdos contemplados na escola, de forma orgânica e sistematizados, objetivando, em linhas gerais, adaptar tal ensino às necessidades e realidades particulares dentro de suas possibilidades e condições. O ensino geral deve ser organizado de forma a ser delineado pelos temas principais. A pesquisa deve despertar na comunidade de investigação uma abertura crítica e reflexiva em torno dos problemas discutidos relacionados aos métodos de pesquisa. A investigação deverá permear as discussões sobre a natureza do ser em suas relações culturais, sociais e transcendentes (HARGREAVES, 2000).

A posição de ter as ciências da religião como área distinta e autônoma já começa a tomar corpo no Brasil nesse período. Com isso, fica cada vez mais claro e definido o fenômeno religioso como objeto de pesquisa, por meio da experiência de vida dos sujeitos envolvidos.

Analisar qual seja a função social das tradições religiosas na atual conjuntura sociocultural, equiparar e distinguir tradições religiosas, digredindo sobre axiologia religiosa (do valor teórico ético para o valor prático moral). Apresentar o fenômeno religioso, expressão das religiões com referência de sentido existencial condicionante na conjuntura da sociedade, elucidando assim, pendências metodológicas da disciplina. Por fim, explicitar tanto sua identidade pedagógica, quanto sua interação disciplinar \& interdisciplinar ao que tange as diferentes denominações em seus contextos diversos.

As categorias de análise do fenômeno religioso não podem ter proselitismos baseados em qualquer dogmatização religiosa. Deve-se produzir 
Religare, ISSN: 19826605, v.16, n.1, agosto de 2019, p.207-227.

uma etnologia das ciências da religião, a qual garanta a todos os cidadãos a isonomia (igualdade de direitos perante a lei), a isotimia (livre acesso ao exercício da participação pública) e a isegoria (igualdade de direito no uso da palavra nas assembleias), e que faça da observância da liberdade à base sobre a qual repousa toda a sociedade política (BONAVIDES, 2006).

Constrói-se uma possibilidade de análise tanto diacrônica / sincrônica, quanto endógena / exógena do fenômeno religioso. Crivada por um intercambio disciplinar religioso dialógico (multi/pluri/inter/trans/meta), mas, acima de tudo, em posição de colocar-se no lugar do Outro. Consiste em levantar, identificar organizar, analisar experiências e expressões religiosas, em exposições das tradições religiosas em suas correlações conjunturais (ZABALA, 2002).

Logo, constitui-se como ciência em interação fenomenológica por meio de todas as ciências possíveis, através de inferências epistemológicas com ciências das religiões. Para além do ecumenismo, desdobrando-se em uma educação transdisciplinar, incidindo diretamente na humanização do sujeito (SOMMERMAN, 2006).

Portanto, deve-se provocar uma simbiose entre Ensino Religioso Escolar e Ciências da Religião, avanço epistemológico, desconstruindo impasses escalafobéticos de intolerância e/ou de verdades obscenas e unilaterais.

Daí que na primeira versão da Base Nacional Comum Curricular (BRASIL, 2015) afirmou-se que a disciplina de Ensino Religioso deve-se ser integrada na área de Ciências Humanas “[...] realçando seu caráter histórico e filosófico" (BRASIL, 2015, p.235). Inclusão a qual converge, segundo o documento, "[...] para o estudo da diversidade cultural religiosa na perspectiva dos direitos humanos" (BRASIL, 2015, p. 237). Haja vista ser o Ensino Religioso um componente curricular "[...] de caráter notadamente não confessional" (BRASIL, 2015, p. 283), o qual assume, na educação básica, a tarefa de propiciar 
Religare, ISSN: 19826605, v.16, n.1, agosto de 2019, p.207-227.

à tradição religiosa uma cosmovisão baseada em pressupostos "científicos, estéticos, éticos, culturais e linguísticos" (BRASIL, 2015, p. 284).

Já na segunda versão do documento da Base Nacional Comum Curricular (BRASIL, 2016), houve uma mudança significativa, onde o Ensino Religioso passou a ser considerado como área própria de conhecimento dentro da especificidade das Ciências Humanas. Constituído como componente curricular de "[...] caráter notadamente não confessional" (BRASIL, 2016, p.171). Mas a novidade mais marcante consiste na perspectiva de que os conhecimentos utilizados pelo Ensino Religioso sejam pautados pelas áreas do conhecimento do campo das Ciências Humanas e Sociais, "notadamente da (s) Ciência (s) da (s) Religião (ões)" (BRASIL, 2016, p.170), constituída então como área de conhecimento independente "[...] cuja natureza e finalidades pedagógicas são distintas da confessionalidade" (BRASIL, 2017, 345).

Com isso, tal proposição tem como perspectiva ultrapassar tanto o modelo catequético, quanto o modelo teológico, para enfim, assumir as Ciências da Religião como proposição, propicia aos sujeitos estudantes tanto autonomia epistemológica, quanto autonomia pedagógica. Consiste em ser maior do que catequese, espiritualidade, educação das religiosidades, e/ou educação de bons valores. Visa à autonomia e a emancipação do sujeito, sendo que, das diversas dimensões que a pessoa possui, a transcendência é uma das que mais se destaca.

\section{A proposição de três modelos}

No Brasil o Ensino Religioso Escolar ainda precisa romper com as velhas práticas já consolidadas, pelos diferentes interesses políticos e econômicos das várias denominações religiosas. Daí a necessidade latente da proposição de um "ensino religioso", sem necessariamente estar ligado a qualquer denominação religiosa. Tal discussão deve ter por base epistemológica as Ciências da 
Religare, ISSN: 19826605, v.16, n.1, agosto de 2019, p.207-227.

Religião, pela qual se constitui uma necessária fundamentação teóricopedagógica efetivada a partir do modelo de religiosidade calcada tanto no Estado democrático de direito, quanto na ética da alteridade (TEIXEIRA, 2011).

Possibilidade construída com mais força depois da publicação da Lei $n^{0}$ 9.475/97, que alterou o Art. $\mathrm{n}^{\mathrm{o}} 33$ da lei $\mathrm{n}^{\mathrm{o}}$ 9.394/96 (LDB), o que privilegia a diversidade religiosa e cultural presente na sociedade, além de coibir quaisquer formas de proselitismo. Tanto definindo conteúdos diversos, quanto composição formativa de professores capazes de lidarem com diferenças expressas nas mais variadas manifestações religiosas.

Permeada por essa formulação secular, fica desvinculada do Ensino Religioso Escolar qualquer forma de proselitismo, necessidade então, de construir propostas teórico-metodológicas capazes de edificar tal discussão através de fundamentação cientifica, a partir do respeito a todas as diversas manifestações religiosas. Porque "não há como negar aos alunos a possibilidade de acesso inteligente ao fato religioso, bem como à compreensão das grandes referências espirituais" (TEIXEIRA, 2011, p. 857), isso é direito de todos.

Nessa confluência, Passos (2007), propõe três modelos possíveis de materializar a disciplina: (a) Catequético doutrinal; (b) Teológico ecumênico; (c) Ciências da religião; Partindo desta perspectiva tipológica, pode-se indagar: Por que três modelos e não outros? Ou ainda um quarto ou quinto modelo, eventualmente, surgido da composição dos três?

Para Soares (2015, p.47-48):

Passos opta por uma visão diacrônica do ER no Brasil, que vai do longo período histórico em que ensinar religião equivalia a iniciar o aluno nos mistérios cristãos (e, principalmente, na tradição católica) até a situação contemporânea, que concilia desconfiança contra as instituições e atração por novas espiritualidades. 
Religare, ISSN: 19826605, v.16, n.1, agosto de 2019, p.207-227.

Por essa razão a disposição dos três modelos nessa sequência cronológica. Sem perder de vista a possibilidade bastante comum na atualidade a qual consiste na mistura dos modelos.

\section{(a) Catequético doutrinal;}

O primeiro, o modelo intitulado catequético doutrinal, sob a perspectiva doutrinária católica do período Colonial e parte no período Imperial, período histórico, o qual não teve problema de ordem alguma para se estabelecer como hegemônico, tornando-se um braço eclesiástico na escola pública como instrumento de continuidade da manutenção do status quo religioso social (SOUZA, 2013).

Nesse modelo, a catequese foi um instrumento fundamental para a busca de novos fiéis mediante a propagação da doutrina cristã no processo de fixação colonial, uma catequese apologética que admoestava a religião oficial do Estado. Pretendia desenvolver a cristandade portuguesa na colônia. Atualmente ainda há resquício de sua prática (PASSOS, 2006).

\begin{tabular}{|c|c|}
\hline \multicolumn{2}{|c|}{ QUADRO I: Modelo Catequético Doutrinal } \\
\hline ELEMENTOS & CARACTERÍSTICAS \\
\hline Cosmovisão & Unireligiosa \\
\hline Contexto Político & Aliança Igreja- Estado \\
\hline Fonte & Conteúdos doutrinais \\
\hline Método & Doutrinação \\
\hline Afinidade & Escola Tradicional \\
\hline Objetivo & Expansão das Igrejas \\
\hline Responsabilidade & Confissões religiosas \\
\hline Riscos & Proselitismos e intolerância \\
\hline
\end{tabular}

Fonte: Passos (2007, p. 59). 
Religare, ISSN: 19826605, v.16, n.1, agosto de 2019, p.207-227.

Soares (2010) delineia esse modelo catequético como um modelo confessional tradicional. O delineamento desse modelo está permeado por uma cosmovisão unireligiosa, compilado por princípios morais do cristianismo, cuja finalidade pedagógica estava na doutrinação da sociedade, com vistas a expandir os tentáculos das Igrejas. O que acabou consolidando a relação entre Igreja e Estado, instrumentalizados pelo ensino religioso confessional, pelo qual se consolidou o paradigma da escola tradicional proselitista crivada pela intolerância religiosa.

No campo educacional, esse modelo está em afinidade ao modelo escolar tradicional, dado pelo método bancário de postura autoritária com conteúdos prefixados. Tem por estratégia no contexto atual da sociedade moderna reconquistar a hegemonia perdida, quando as confissões religiosas se impunham como referência. Oficialmente veio a ser corroborado pelo sistema nacional de ensino em 1961, pela LDBEN n 4.024/61.

Atualmente o estudo do fenômeno religioso se dá a partir da escola, por uma noção sociológica e não mais doutrinária. Independente de qual possa ser a denominação de referência. O exercício de uma religiosidade é agora tratado sob uma perspectiva pessoal. Modelo de caráter proselitista e de intolerância religiosa, em uma sociedade onde a separação entre Igreja e Estada está efetivada, é pouco provável que esse modelo consiga alcançar êxito epistemológico (SILVA, 2017).

\section{(b) Teológico Ecumênico;}

O segundo modelo intitulado Teológico Ecumênico, sob a perspectiva antropológica e secularizado do fim do período imperial e início do republicano. Sua caracterização se deu pela superação do modelo catequético confessional e atender de forma mais ampla a sociedade secularizada que se 
Religare, ISSN: 19826605, v.16, n.1, agosto de 2019, p.207-227.

desenvolveu sob uma perspectiva a partir da partir da LDB no 5.692/71. Apesar de ter sofrido influência direta do Concílio Vaticano II realizado na década de 1960. Contudo, ainda tinha um lastro confessional religioso, o que acabou se caracterizando como continuidade do modelo catequético anterior (SOUZA, 2013).

Esse modelo empreendeu uma disposição democrática de uma noção ecumênica entre diversas denominações religiosas, sob um viés interdisciplinar na conjuntura escolar, carregado de um discurso afinado com a modernidade, avoca um diálogo inter-religioso com a sociedade em vistas de uma formação integral dos sujeitos (PASSOS, 2006).

\begin{tabular}{|c|c|}
\hline \multicolumn{2}{|c|}{ QUADRO II: Modelo Teológico Ecumênico } \\
\hline ELEMENTOS & CARACTERÍSTICAS \\
\hline Cosmovisão & Plurirreligiosa \\
\hline Contexto Político & Sociedade secularizada \\
\hline Fonte & Indução \\
\hline Método & Escola nova \\
\hline Afinidade & Formação religiosa dos cidadãos \\
\hline Objetivo & Confissão religiosa \\
\hline Responsabilidade & Catequese disfarçada \\
\hline Riscos &
\end{tabular}

Fonte: Passos (2007, p. 63).

Soares (2010) delineia esse modelo teológico ecumênico como um modelo pluralista, inclusive aceitando religiões não cristãs. Tendo como centralidade da questão o fato de que ainda não tenha uma liderança com poder decisório de veto sobre conteúdos discrepantes a serem discutidos no chão da sala de aula.

O delineamento desse modelo está permeado por uma cosmovisão plurirreligiosa, compilada através de uma sociedade secularizada, crivada por 
Religare, ISSN: 19826605, v.16, n.1, agosto de 2019, p.207-227.

uma teologia pluralista antropológica, com vistas a uma formação religiosa cidadã, mesclando diretrizes tanto das instituições religiosas, quanto do ideário pedagógico da Escola Nova. Entende a religiosidade como uma dimensão integrante do ser humano, sendo, portanto, um valor importante a ser educado. Caracteriza-se ainda por um avanço como tentativa de superação da cristandade medieval, por isso assume uma cosmovisão plurirreligiosa. Mas, ainda se constituí como modelo negativo pela incapacidade crítica de avanço em relação à lógica catequética (PASSOS, 2007).

Contudo, a produção dos conteúdos lecionados, bem como, a formação docente, ainda era de responsabilidade dos sistemas religiosos, o que acabou produzindo uma catequese disfarçada. Como não existe teologia supraconfissional, menos ainda aconfissional, esse modelo acabou por produzir uma ação catequética de forma dissimulada, o que iria de encontro ao princípio de laicidade do Estado moderno, gerando por tanto novas polemicas (SENA, 2007).

No campo pedagógico o modelo encontrou respaldo com a Escola Nova, por também ter método indutivo e valorizar a individualidade dos sujeitos. Destacou-se por afirmar a dialogicidade de valor inter-religioso concebido pela pluralidade religiosa. Sua cosmovisão educacional partia do processo de humanização da pessoa dado por um agir ético no mundo.

Assim, o sujeito é entendido como um ser infinito, aberto à transcendência, onde a educação caminha nessa perspectiva de formação para um horizonte maior de sociedade justa e livre. Sua metodologia usava a argumentação racional teológico-confessional, onde a filosofia era a serva da teologia (SILVA, 2017).

Contudo, nenhum dos dois modelos deu contas das exigências da escola laica que se sobressaia naquele contexto histórico, assim, fez-se necessário uma 
Religare, ISSN: 19826605, v.16, n.1, agosto de 2019, p.207-227.

terceira via que melhor garantisse esses processos didático-pedagógicos e epistemológicos do Ensino Religioso.

\section{(c) Ciências da Religião;}

O terceiro modelo calcado na noção das Ciências da Religião, onde o Ensino Religioso adquire o status de autonomia enquanto área de conhecimento com objeto específico (o fenômeno religioso) e estatuto pedagógico próprio, integrada ao currículo escolar. Também é denominado como modelo fenomenológico, onde as religiões transcendem o escopo do privado, constituindo a singularidade do fenômeno religioso (SOUZA, 2013).

Outra característica que se destaca nesse modelo é o fato de o objeto de investigação ser "maior do que a confessionalidade presente em cada denominação religiosa" (JUNQUEIRA; CORRÊA; HOLANDA, 2007, p. 51). Logo, o professor da disciplina não precisa mais ser um teólogo, mas sim, um cientista da religião com apropriada capacitação didático-pedagógico.

Nesse modelo, o fenômeno religioso enquanto fenômeno humano, produção histórica e sociocultural não dogmatizada como princípio de fé, mas sim, como Ciências da Religião. A qual se torna mais uma das inúmeras ciências que estuda o fenômeno da religião, o qual consiste em ser mais um dos inúmeros fenômenos de compreensão da realidade vivida (PASSOS, 2006).

\begin{tabular}{|c|c|}
\hline \multicolumn{2}{|c|}{ QUADRO III: Modelo das Ciências da Religião } \\
\hline ELEMENTOS & CARACTERÍSTICAS \\
\hline Cosmovisão & Transreligiosa \\
\hline Contexto Político & Sociedade secularizada \\
\hline Fonte & Ciências da Religião \\
\hline Método & Indução \\
\hline Afinidade & Epistemologia atual \\
\hline
\end{tabular}


Religare, ISSN: 19826605, v.16, n.1, agosto de 2019, p.207-227.

\begin{tabular}{|c|c|}
\hline Objetivo & Educação cidadã \\
\hline Responsabilidade & Comunidade científica e do Estado \\
\hline Riscos & Neutralidade científica \\
\hline
\end{tabular}

Fonte: Passos (2007, p. 66).

O delineamento desse modelo está permeado por uma cosmovisão secularizada e transreligiosa, compilado por uma construção epistemológica fundamentada na transdisciplinariedade. Construída por uma educação autônoma e emancipada de neutralidade cética do fenômeno religioso. Baseado na redação da LDB no 9.394/96, com a nova redação do artigo no 33, posteriormente retificado pelas Resolução CEB/CNE nº 02 de 07 de abril de 1998, a qual institui as Diretrizes Curriculares Nacionais para o Ensino Fundamental e a Resolução CNE/ no 07 de 14 de dezembro de 2010, a qual fixa as Diretrizes Curriculares Nacionais para o Ensino Fundamental de 09 (nove) anos, as quais situam o Ensino Religioso como área de conhecimento.

Soares (2009) conclui com a consciência de que se faz necessário confrontar as diferentes noções epistemológicas, a fim de desconstruir qualquer mal entendido doutrinário. Propondo-se ser mais do que catequético, superando limites, sendo pedagógico; propiciando aos sujeitos condições gradativas de humanização da escola como um todo.

Finalmente, as dificuldades se fazem presentes devido ao processo de politização da disciplina, a qual ainda se situa no campo de disputa entre Igreja e Estado. Mas, com um indicativo de alternativa regulamentado pela Lei $\mathrm{n}^{\underline{0}}$ 9.475/97, a qual possibilita a afirmação de um modelo secularizado baseado “um perfil pedagógico de releitura das questões religiosas da sociedade, baseado na compreensão de "área de conhecimento" e orientado pelos Parâmetros Curriculares Nacionais. (OLIVEIRA et al., 2007, p. 58).

\section{Proposições Pedagógicas}


Religare, ISSN: 19826605, v.16, n.1, agosto de 2019, p.207-227.

Nessa perspectiva pedagógica, a formação continuada do docente em voga deve ter um domínio epistemológico apropriado das Ciências da Religião. O problema a ser enfrentado ainda consiste em ter diversos preconceitos cristalizados, os quais estancam a discussão pedagógica fundamental, a começar pela nomenclatura de "Ensino Religioso", quando abreviado, apenas por "Religião". Por isso, a necessidade da implementar um projeto pedagógico através de revisões e atualizações curriculares, que possa estabelecer diretrizes próprias para o Ensino Religioso (DANTAS, 2004).

Logo, faz-se necessário abandonar a caracterização expressa no nome "Ensino Religioso" e, em seguida, adentrar no complexo universo acerca do que seja Ciências da Religião, o que tange aproximações científicas com o fenômeno religioso. Enquanto a Ciência da Religião identifica quais devem ser os procedimentos metodológicos a serem seguidas pelos cientistas da religião, a fim de delinear o seu objeto particular. Continuando com uma conjectura pedagógica que a classifique cientificamente a contento. Então a área do Ensino Religioso, "para além de uma disciplina que traga a história das religiões, como o querem alguns, uma disciplina capaz de trazer um conhecimento e, ao mesmo tempo, a necessária reflexão sobre o sentido da vida" (CÂNDIDO, 2007, p.265), passa a ser tratado como Ciências das Religiões:

Parece ser inevitável, a essa altura, amainar os ânimos exaltados, causados pelas tensões surgidas entre as diferentes ciências, bem como, distinguir a pertinência de cada uma delas ou, ainda, transformá-las em espaços multidimensionais, transculturais e transdisciplinares. Por fim, quais conteúdos devam contemplar a estrutura curricular das Ciências da Religião?

Nessa perspectiva, faz-se necessário construir relações intrínsecas com todas as ciências para entender Ciências da Religião como área de conhecimento. O que se propõe enquanto fundamento da disciplina não é o de assegurar aos sujeitos o direito de expressarem ou não alguma religiosidade, 
Religare, ISSN: 19826605, v.16, n.1, agosto de 2019, p.207-227.

mas sim, o direito a uma educação que lhe propicie a compreensão existente entre as diferentes manifestações socioculturais religiosas (PASSOS, 2007).

Nessa discussão, pretende-se estabelecer as Ciências da Religião como disciplina autônoma e equivalente a qualquer outra disciplina da estrutura curricular educacional formal. Infelizmente ainda não existe uma definição epistemológica que defina a característica do conhecimento produzido por meio da vivência religiosa. Ainda há uma oscilação entre quais procedimentos pedagógicos devam decorrer desta disciplina (SOARES, 2015).

Por causa do jogo de interesses envolvidos, essa proposição, ora tende para o modelo catequético, ora tende para o modelo teológico, ora tende para o modelo das Ciências da Religião. Atividade que consiste no estabelecimento epistemológico da disciplina, pelo qual transparece tensões entre a liberdade religiosa, laicidade da escola e ideologias dissimuladas pelas diferentes manifestações religiosas que não querem perder espaço (DANTAS, 2004).

Talvez esse último item seja o mais latente nessa guerra dos deuses, pois existem diversos interesses em jogo, tanto das instituições religiosas, quanto pessoais, além das tensões tradicionais das escolas em detrimento aos inúmeros interesses destoantes das várias disciplinas já constituídas.

Almeja-se constituir um modelo pedagógico disciplinar que possa superar todas as tensões de poder e todos os impasses confessionais, os quais historicamente já disputam por espaços cada vez mais hegemônicos e doutrinários. Nas palavras de Laclau (2006, p. 24), “a hegemonia é isso: uma particularidade que assume uma certa função universal".

Se todas essas tensões podem substituir as promoções da alteridade do sagrado, quem mais ganharia com isso seria o estudante, por se apropriar de forma autônoma desse fenômeno sociocultural antropológico. Condição necessária para o desvinculamento da confessionalidade do proselitismo na área de conhecimento das Ciências da Religião (ROBBINS, 2008). 
Religare, ISSN: 19826605, v.16, n.1, agosto de 2019, p.207-227.

Por isso, toma-se o modelo das Ciências da Religião como pressuposto epistemológico e pedagógico de estudo do fenômeno religioso sem proselitismo, haja vista ser uma área de conhecimento relativamente nova, fundamentada na religiosidade humana, por meio da análise dos elementos comuns às várias manifestações religiosas, expressas em suas multiplicidades. Assim, maior do que a confessionalidade religiosa está a o fenômeno religioso enquanto manifestação humana a ser estudado em suas mais variadas tradições (MENEGHETTI, 2003).

Faz-se necessário destacar qual seja a necessidade epistemológica na construção da disciplina do Ensino Religioso Escolar, viabilizando diálogo epistemológico, transitando nas diversas áreas como meio de entendimento e interpretação da compreensão humana existencial (COSTELLA; OLIVEIRA, 2007).

Dessa forma, a sua epistemologia propicia investigação por meio de seu sentido filosófico, assumindo a religião / religiosidade como subjetividade humana, dialógica onde se transita diferenças, tanto ao nível objetivo de experiência humana como pensante, quanto ao nível subjetivo da existência como crente.

Por fim, Soares (2010), conclui essa abordagem postulando questões do fenômeno religioso como uma exposição panorâmica das relações socioculturais das religiões, tratando-se, portanto, de um enfoque multidisciplinar, pelo qual transita tanto de forma horizontal quanto vertical pelas ciências, construindo uma pedagogia que realmente seja multidisciplinar.

\section{Considerações Finais}


Religare, ISSN: 19826605, v.16, n.1, agosto de 2019, p.207-227.

Feitas essas análises e reflexões, fica demonstrado como o fenômeno religioso pode propiciar uma cultura de tolerância para uma convivência harmônica entre concepções díspares.

Tal proposição analítica considerou tanto $\mathrm{o}$ respeito quanto à diversidade, assegurados na atualidade pela legislação educacional constituída.

No campo didático, no tocante à formação dos Professores, ainda existem lacunas a serem preenchidas, principalmente na prática pedagógica de formação, para que seja uma ação pedagógica em consonância com a legislação sobre a disciplina escolar do Ensino Religioso.

O Ensino Religioso Escolar, como disciplina do corpo integrante do currículo básico de formação cidadã, demonstra um respeito humano fundamental, expresso pela lei no 9.475/97.

Esse paradigma atual das Ciências da Religião transcende a proposição cartesiana disciplinar e constrói uma epistemologia transreligiosa, construída pela fé experimentada pelos grupos humanos e não da dogmatização religiosa unilateral.

Espera-se que essa digressão possa contribuir para uma maior e melhor qualificação do trabalho docente da disciplina do Ensino Religioso Escolar. Construindo um campo de pesquisa inovador a ser explorado no chão da escola, ao ponto de romper com sérios problemas epistemológicos, metodológicos, pedagógicos e didáticos, muito comuns entre educadores que ainda insistem equivocadamente em concepções proselitistas de determinadas crenças religiosas.

\section{Referências}

BOGDAN, R. C.; BIKLEN, S. K. Investigação qualitativa em educação: uma introdução à teoria e aos métodos. Porto: Porto Editora, 1994. (Coleção Ciências da Educação). 
BONAVIDES, Paulo. Ciência Política. 12ª Edição. São Paulo: Malheiros, 2006.

BRASIL. Ministério da Educação. Base Nacional Comum Curricular do Ensino Básico. Brasília, 2015, 303p. Disponível em: <http://movimentopelabase.org.br/wp-content/uploads/2017/04/BNCCAPRESENTACAO_final_06-10.pdf>. Acesso em: 10 jan. 2019.

BRASIL. Ministério da Educação. Base Nacional Comum Curricular do Ensino Básico. Brasília, 2017, 600p. Disponível em: $<$ http://basenacionalcomum.mec.gov.br/wpcontent/uploads/2018/12/BNCC_19dez2018_site.pdf>. Acesso em: 10 jan. 2019. BRASIL. Ministério da Educação. Base Nacional Curricular Comum do Ensino Básico. 2 ${ }^{a}$ versão revista. Brasília, 2016, 652p. Disponível em: $<$ http://historiadabncc.mec.gov.br/documentos/bncc-2versao.revista.pdf>.

Acesso em: 10 jan. 2019.

BRASIL. Ministério da Educação. Lei no 9.394/96, Diretrizes e Bases da Educação Nacional. Brasília: Diário Oficial da União, 20 de dezembro de 1996, Secção I, Art. 33.

BRASIL. Ministério da Educação. Lei no 9.475/97, dá nova redação ao Art. 33 da Lei no 9.394, de 20 de dezembro de 1996, que estabelece as Diretrizes e bases da Educação Nacional. Brasília: Diário Oficial da União, 23 de Julho de 1997, Secção I.

BRASIL. Ministério da Educação. Resolução CNE/ nº 07 de 14 de dezembro 2010. Fixa as Diretrizes Curriculares Nacionais para o Ensino Fundamental de 09 (nove) anos. Disponível em: <http://portal.mec.gov.br/dmdocuments/rceb007_10.pdf $>$. Acesso em: 10 jan. 2019.

BRASIL. Ministério da Educação. Resoluções CEB/CNE nº 02 de 07 de abril de 1998. Institui as Diretrizes Curriculares Nacionais para o Ensino Fundamental. Disponível em: $<$ http://portal.mec.gov.br/dmdocuments/resolucao_ceb_0298.pdf>. Acesso em: 10 jan. 2019.

CÂNDIDO, Viviane Cristina. Ensino Religioso na Educação Infantil: Ênfase na construção de uma área de conhecimento pela proposição de temas específicos. Revista Lusófona de Ciência das Religiões. Ano VI, no 12. 2007, p.263-270. Disponível em: <http://recil.ulusofona.pt/bitstream/handle/10437/4178/ensino_religioso_na_edu cacao_infantil.pdf?sequence=1>. Acesso em: 10 jan. 2019.

COSTELLA, Domenico; OLIVEIRA, Ednilson Turozi. Epistemologia do Ensino Religioso. Religião \& Cultura. São Paulo, vol. VI - no 11 Jan/Jun. 2007, p. 43-56. Disponível em: <http://www.gper.com.br/noticias/ece4bfcc5ac497d065907b94a6192b80.pdf>. Acesso em: 29 ago. 2017. 
DANTAS, Douglas Cabral. O ensino religioso escolar: modelos teóricos e sua contribuição à formação ética e cidadã. Horizonte: Revista de Estudos de Teologia e Ciências da Religião, Belo Horizonte, vol. 2, no 4, p. 112-124, jan./jun. 2004.

Disponível

em: $<$ http://periodicos.pucminas.br/index.php/horizonte/article/view/583>. Acesso em: 11 jan. 2019.

FONSECA, J. J. S. Metodologia da pesquisa científica. Fortaleza: UEC, 2002. Apostila.

FÓRUM NACIONAL PERMANENTE DE ENSINO RELIGIOSO (FONAPER). Parâmetros Curriculares Nacionais: Ensino Religioso. 4⿳亠丷a ed. São Paulo: Ave Maria, 2001.

HARGREAVES, Andy. Aprendendo a mudar. O ensino para além dos conteúdos e da padronização. Porto Alegre: Artmed, 2000.

JUNQUEIRA, Sergio R. A.; CORRÊA, Rosa L. T.; HOLANDA, Ângela Maria R. Ensino religioso: aspectos legal e curricular. São Paulo: Paulinas, 2007.

LACLAU, Ernesto. Inclusão, exclusão e a construção de identidades. In: AMARAL Jr., Aécio; BURITY, Joanildo (Org.). Inclusão social, identidade e diferença. São Paulo: Annablume, 2006, p.21-37.

MENEGHETTI, Rosa G. K. A Pertinência Pedagógica da Inclusão do Ensino Religioso no Currículo Escolar. In: GUERRIERO, Silas (org.). O estudo das religiões: desafios contemporâneos. 2ª ed. São Paulo: Paulinas, 2003, p. 89-99.

MINAYO, M. C. S. (Org.) Pesquisa social: teoria, método e criatividade. Petrópolis: Vozes, 2001.

OLIVEIRA, Lilian Blanck; JUNQUEIRA, Sergio R. A.; ALVES, Luiz A. S.; KLIM, Ernesto J. Ensino Religioso: fundamentos e métodos. São Paulo: Cortez, 2007.

PASSOS, João Décio. Ensino religioso: construção de uma proposta. São Paulo: Paulinas, 2007.

PASSOS, João Décio. Ensino religioso: mediações epistemológicas e finalidades pedagógicas. In: SENA, Luiza (Org.). Ensino religioso e formação docente. São Paulo: Paulinas, 2006.

ROBBINS, Joel. Sobre alteridade e o sagrado em uma época de globalização. O "trans" em "transnacional" é o mesmo "trans" de "transcendente"? Mana. Vol.14, $\mathrm{n}^{\mathrm{o}}$ 01. Rio de Janeiro, Abr. 2008, p.119-139. Disponível em: <http://www.scielo.br/pdf/mana/v14n1/a05v14n1.pdf>. Acesso em: 29 dez. 2017. SANTOS, Akiko; SOMMERMAN, Américo. Complexidade e transdisciplinaridade: em busca da totalidade perdida. Porto Alegre: Sulina, 2009.

SANTOS, Lauren Aparecida de Souza. Alteridade na educação: o sentir o si e o outro. 2015. 89 f. Dissertação (Mestrado em Educação). Universidade Federal de São Carlos, São Carlos, 2015. Disponível em: $<$ https://repositorio.ufscar.br/bitstream/handle/ufscar/7313/DissLASS.pdf?seque nce=1>. Acesso em: 29 dez. 2017. 
SENA, Luzia. Ensino religioso e formação docente: ciências da religião e ensino religioso em diálogo. São Paulo: Paulinas, 2007.

SILVA, Ronald Lima da. Novos Panoramas Para o Ensino Religioso: Uma análise do modelo das Ciências da Religião para o Ensino Religioso nas escolas públicas, tendo em vista aspectos da transdisciplinaridade, transreligiosidade e pluralismo religioso. 2017, 149f. Dissertação (Mestrado em Ciências da Religião). Universidade Metodista de São Paulo. São Bernardo do Campo, 2017. Disponível em: <http://tede.metodista.br/jspui/handle/tede/1661>. Acesso em: 10 jan. 2019.

SOARES, Afonso Maria Ligorio. A contribuição da Ciência da Religião para a formação de docentes ao Ensino Religioso. Rever, Ano 15, no 02, jul./dez., 2015. Disponível

em: $<$ http://revistas.pucsp.br/index.php/rever/article/viewFile/26183/18847>. Acesso em: 10 jan. 2019.

SOARES, Afonso Maria Ligorio. Ciência da Religião, Ensino Religioso e Formação Docente. Revista de Estudos da Religião. São Paulo, vol. 09, no 09, set. 2009, p. 01-18. Disponível em: <http://www.pucsp.br/rever/rv3_2009/t_soares.pdf>. Acesso em: 10 jan. 2019.

SOARES, Afonso Maria Ligorio. Religião E educação: da ciência da religião ao ensino religioso. São Paulo: Paulinas, 2010. (Coleção temas do ensino religioso). SOMMERMAN, Américo. Inter ou Transdisciplinaridade? Da fragmentação disciplinar ao novo diálogo entre os saberes. Coleção Questões Fundamentais da Educação. 71 à ed. São Paulo: Paulus, 2006.

SOUZA, Rodrigo Augusto de. Novas perspectivas para o ensino religioso: a educação para a convivência e a paz. Revista Reflexão e Ação. Santa Cruz do Sul, vol.21, $\mathrm{n}^{\mathrm{o}}$ 01, jan./jun. 2013, p.25-49. Disponível em: $<$ https://online.unisc.br/seer/index.php/reflex/article/view/3207>. Acesso em: 10 jan. 2019.

TEIXEIRA, Faustino. O "ensino do religioso" e as Ciências da Religião. Horizonte: Revista de Estudos de Teologia e Ciências da Religião. Belo Horizonte, vol. 09, $\mathrm{n}^{\mathrm{o}}$ 23, out/dez, 2011, p.839-861. Disponível em: $<$ http://periodicos.pucminas.br/index.php/horizonte/article/view/P.21755841.2011v9n23p839>. Acesso em: 10 jan. 2019.

ZABALA, Antoni. Enfoque Globalizador e Pensamento Complexo: Uma proposta para o currículo escolar. Porto Alegre: ARTMED, 2002.

Recebido em 27/06/2018. Aprovado em 11/07/2019. 